\title{
The Effect Of Organizational Commitment To Turnover Intention
}

\author{
Sihombing, Irene Hanna $\mathrm{H}$. \\ Hotel Administration \\ STP Nusa Dua Bali \\ Bali, Indonesia \\ henry_irene@yahoo.com
}

\author{
Ni Made Regina Maharatih \\ Hotel Administration \\ STP Nusa Dua Bali \\ Bali. Indonesia \\ reginamaharatih@yahoo.com
}

\author{
I Nyoman Sukana Sabudi \\ Hotel Administration \\ STP Nusa Dua Bali \\ Bali, Indonesia \\ nsabudi@yahoo.com
}

\begin{abstract}
This study was conducted to determine the effect of organizational commitment on turnover intention. Respondents numbered 81 people from all departments in the hotel. Questionnaires with a 5point Likert scale were used to measure 21 indicators of organizational commitment and turnover intention. Data analysis techniques use Simple Regression Analysis techniques. The results of this study indicate that organizational commitment has a significant negative effect on turnover intention at Ayodya Resort Bali. In addition, organizational commitment contributes to turnover intention of $46.8 \%$. Other variables outside the research model have a contribution of $53.2 \%$. Continuance commitment has the lowest average value among the three dimensions of organizational commitment. So that this should be a concern for management to be able to increase continuance commitment.
\end{abstract}

Keywords-Organizational Commitment, Turnover Intention

\section{INTRODUCTION}

Tourism is a very important sector for developing countries according [1], tourism has a significant effect on the opening of new employment opportunities, the increase in income, the welfare of the people, the growth of micro-economic activities, and the reduction in the number of poor people. To support tourism activities, supporting facilities such as accommodation are needed. Accommodation is an important part of the tourism sector, along with communication and restaurants [2]. One type of accommodation that exists to meet tourism needs is the hotel. Hotels are one of the growing business fields in the field of accommodation that is in desperate need of competent and qualified human resources, especially in this era of globalization. With quality resources expected to be able to improve hotel performance in running its business. Along with the development of a company, it will cause various problems related to human resources, one of which is turnover intention.
Turnover intention is a conscious desire and intentional willingness to leave the organization [3]. Turnover intention defined as an employee's desire to leave the organization [4]. High turnover has a serious impact on the company. High turnover has a negative impact as the organization must pay a small amount in the replacement of employees as a consequence, the organization must pay most of its time to recruit and choose activities that will increase administrative responsibility [5]. One factor that has a relationship with turnover intention is organizational commitment. Some researchers have examined the relationship between organizational commitment to turnover intention. There are several factors that influence turnover intention, one of which is organizational commitment that has been found as the main factor influencing employee turnover intention [6]. Organizational commitment defined as a strong belief in achieving organizational goals and values, willingness to mobilize a lot of effort on behalf of the organization and a strong desire to remain a member of the organization [7]. Organizational commitment is also interpreted as a psychological approach between employees and organizations that has implications for employee decisions to survive or leave the organization [8]. This study aims to determine how the influence between organizational commitment and turnover intention using simple regression methods. This research was conducted at the Ayodya Resort Bali hotel located on Pantai Mengiat Nusa Dua Street.

\section{LITERATURE}

\section{Organizational Commitment and Turnover Intention}

Based on the organizational commitment model proposed by Meyer and Allen [8] and its relationship to turnover intention, several previous researchers, conducted a study on the relationship between the three dimensions of 
organizational commitment to turnover intention using samples from university students and employees who work in several organizations [9]. The results obtained from the relationship between the three dimensions of organizational commitment and turnover intention are negative. It was also states that these three dimensions of organizational commitment have different relationship strengths with turnover intention. For example, affective commitment has a stronger correlation with turnover intention compared to normative or continual commitment.

\section{RESEARCH METHODS}

This study uses a simple regression method and partial hypothesis testing. Specifically, this study was conducted to determine the effect of organizational commitment on turnover intention. The research was carried out in one of the 5-star hotels in the ITDC area, Ayodya Resort Bali, located on Pantai Mengiat Nusa Dua Street. Using the proportionate random sampling method, sampling was divided into 10 departments in Ayodya Resort Bali using the Slovin formula. The number of samples from each department presented in Table 1.

TABLE 1 TOTAL POPULATIONA AND SAMPLE

\begin{tabular}{cccc}
\hline No & Department & $\boldsymbol{\%}$ & Sample \\
\hline $\mathbf{1}$ & Front Office & $7.62 \%$ & 10 \\
\hline $\mathbf{2}$ & House Keeping & $20.95 \%$ & 18 \\
\hline $\mathbf{3}$ & Food and Beverage & $42.06 \%$ & 32 \\
\hline $\mathbf{4}$ & Accounting & $3.81 \%$ & 3 \\
\hline $\mathbf{5}$ & Human Resources & $0.63 \%$ & 1 \\
\hline $\mathbf{6}$ & Sales and Marketing & $1.75 \%$ & 2 \\
\hline $\mathbf{7}$ & Purchasing & $1.11 \%$ & 1 \\
\hline $\mathbf{8}$ & Engineering & $7.94 \%$ & 9 \\
\hline $\mathbf{9}$ & Security & $4.44 \%$ & 4 \\
\hline $\mathbf{1 0}$ & IT & $0.63 \%$ & 1 \\
\hline \multicolumn{3}{c}{}
\end{tabular}

Data was collected using a questionnaire with a Likert scale using five criteria, namely: strongly agree, agree, neutral, disagree, and strongly disagree. Simple regression analysis was used to determine the relationship between two variables. The questionnaire was distributed for 10 days and filled in completely. The indicators used in compiling the questionnaire in this study were taken from the previous research [10] and [11].

\section{RESULT AND DISCUSSION}

\section{1) Characteristics of Respondents}

The respondents were divided into several characteristics, such as department, age, education, gender and tenure. Especially for department-based characteristics, the distribution of respondents uses the proportionate stratified random sampling method.

It can be concluded that the majority of respondents by department are food and beverage with the percentage of respondents by 40 percent and second place is housekeeping by $22 \%$, this causes more male employees to work compared to women seen from the type of work who tend to use physical power at the department. From the history of Ayodya Resort Bali which was established in 1990, the majority of respondents based on age are in the category above 35 years with the number of respondents as much as 44 percent and have a tenure of more than 10 years where the majority of education strata are at Diploma 1 level. This means that Ayodya Resort Bali employees tend to be in the same period of work where the majority of their education are at Diploma 1 level and in accordance to the Human Resources Department that craft level requires technical skills and is ready to work so that service to hotel guests can be done effectively and efficient. This is in line with the previous research [12] which states that employees who have high organizational commitment have a longer working period at the organization where they work and tend to want to be able to continue to be in the middle of the organization where they work.

\section{2) The Effect Organizational Commitment and Turnover Intention}

\section{TABLE 2 COEFFICIENTS}

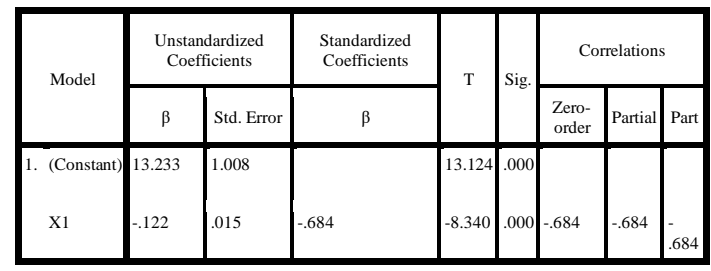

In Table 2, the results of the variables of organizational commitment are explained further through a partial test. So based on the results of the analysis, it is produced that organizational commitment has a significant negative effect on turnover intention which is shown through the value of $\mathrm{t}$ and Sig. $<0.05$. 
Table 2 states that organizational commitment has a $\beta$ value of -0.684 and a Sig. equal to 0,000 . The $\beta$ of organizational commitment has a negative value which means that the relationship of organizational commitment to turnover intention is negative. Thus, the $\beta$ value is negative and the Sig value. $0,000<0,05$ so $\mathrm{H}_{1}$ is rejected and $\mathrm{H}_{0}$ is accepted. That is, the conclusion that can be drawn is that organizational commitment has a significant negative effect on turnover intention.

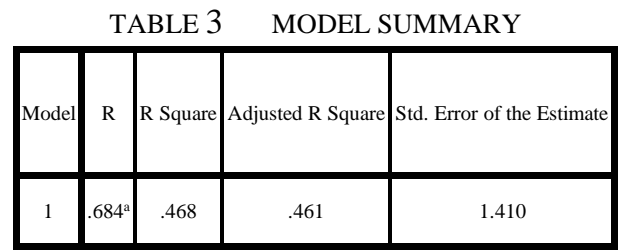

Table 3 shows that the the relationship between organizational commitment to turnover intention gives $\mathrm{R}^{2}$ results of: 0.468 which means that organizational commitment variable contributes to turnover intention of $46.8 \%$. Other contributions of $53.2 \%$ are determined by other variables outside this model.

\section{3) Influence of Organizational Commitments to Turnover Intention}

In accordance with the results of the study related to the variables of organizational commitment and turnover intention that have been made at Ayodya Resort Bali, in general, the problem formulation has been answered in accordance with the hypothesis that has been proposed. Affective commitment, normative commitment, and ongoing commitment have a strong influence on turnover intention. The organizational commitment variable has a strong contribution of $46.8 \%$ to turnover intention and the remaining $53.2 \%$ is determined by other variables outside this model. Organizational commitment has proven to have a significant negative effect on turnover intention at Ayodya Resort Bali. Organizational commitment can be said to have a contribution in suppressing the level of turnover felt by employees. The $\beta$ value of organizational commitment is -0.684 which means that when organizational commitment is at its highest point it will have a large influence and give the effect of turnover intention at the lowest point. This is in line with the research conducted by Meyer and Allen (1991) which states that organizational commitment has a significant negative relationship to turnover intention.

\section{CONCLUSION}

Organizational commitment has a $\beta$ value of 0.684 and a Sig. value equal to 0,000 . This means that organizational commitment has a significant negative effect on turnover intention at Ayodya Resort Bali. Organizational commitment variable contributes $46.8 \%$ to turnover intention and the rest is determined by other variables outside this research.

The management can make decisions and policies that can increase employee organizational commitment, especially continuance commitment. So that it can increase the sense of belonging and kinship towards the hotel. In addition, it is also important for management to understand that there are other things beyond organizational commitment that can reduce turnover intention.

Organizational commitment and turnover intention are interesting themes to develop. Future researchers are expected to be able to research this topic in a different context. Subsequent research is expected to continue research by using more references on organizational commitment and turnover intention especially in using instruments and indicators of turnover intention. Adjustment of the use of instruments and indicators is a good thing to do to achieve accuracy in measuring the variables of this study.

\section{REFERENCES}

[1] Darmawan, D. H dan Adi Y. 2016. Peluang Pariwisata Dalam Menurunkan Kemiskinan di Era Masyarakat Ekonomi Asean (MEA). Journal of Research In Economics And Management.Volume 16 no 2, page 199-213.

[2] Cozea, F. 2013. Urban Accommodation Infrastructure in Cluj Napoca City (Romania). Scientific Annals of Alexandru Ioan Cuza University Of Iasi. Volume LIX, no.1. page 191-208.

[3] Tett, R. P. dan Meyer, J. P. 1993. Job Satisfaction, Organizational Commitment, Turnover Intention: Path Analyses Based On Meta-Analytic Findings. Personnel Psychology. Volume 46, page 259-293.

[4] Kaur, B. 2013. Antecedents of Turnover Intentions: A Literature Review. Global Journal of Management and Business Studies. Volume 3 no 10, page 12191230 .

[5] Saeed, I. 2001. The Relationship of Turnover Intention with Job Satisfaction, Job Performance, Leader Member Exchange, Emotional Intelligence and Organizational Commitment. International Journal of Learning \& Development. Volume 4 no 2, page 242256.

[6] Loi, R, Ngo H dan Sharon F. 2006. Linking Employees' Justice Perceptions To Organizational Commitment And Intention To Leave: The Mediating Role Of Perceived Organizational Support. Journal of Occupational and Organizational Psychology, Volume 79, Page 101-120.

[7] Azeem, S. M. 2010. Job Satisfaction and Organizational Commitment among Employees in the Sultanate of 
Oman. Journal of Psychology, Volume 1 (4), page 295-299.

[8] Allen, J. N. dan Meyer, J. P. 1991. The measurement and Antecedents of Affective, Continuance and Normative Commitment to The Organization. Journal of Occupational Psychology. Volume 63, page 1-18.

[9] Stephen, J. J. 1995. An Assessment of Meyer and Allen's Three Component Model of Organizational Commitment and Turnover Intentions. Academy of Management Journal. Proquest, 317.

[10] Sihombing, I. H. H, Supartha W. G, Made S, and Dewi G. A. M. 2017. The Role of Organizational Commitment Mediating Job Satisfaction and Work Motivation with Knowledge-Sharing Behavior in 4
Star Hotels in Badung Regency, Bali. Global Business \& Finance Review, Volume. 22, page 61-76.

[11] Lum, L, Kervin J, Clark K, Rei F, dan Sirola W. 1998. Explaining Nursing Turnover Intent: Job Satisfaction, Pay Satisfaction, Or Organizational Commitment? Journal of Organizational Behavior, Volume 19 no 3 , page 305-320

[12] Hadiyani, M. I, Diah K dan Tri M. I. 2012. Perbedaan Komitmen Organisasi Ditinjau dari masa kerja karyawan. Prosiding Seminar Nasional. Page 157 175. 